\title{
Landscaping of Quinoline based Heterocycles as Potential Antimicrobial Agents: A Mini Review
}

\author{
Nisheeth C Desai ${ }^{1 *}$, Bonny Y Patel ${ }^{1}$, Krunalsinh A Jadeja ${ }^{1}$ and Bharti P Dave ${ }^{2}$ \\ ${ }^{1}$ Division of Medicinal Chemistry, Department of Chemistry (DST-FIST Sponsored \& UGC NON-SAP), Maharaja Krishnakumarsinhji Bhavnagar \\ University, Bhavnagar-364002, India \\ ${ }^{2}$ Department of Life Sciences, Maharaja Krishnakumarsinhji Bhavnagar University, Bhavnagar, India
}

Submission: April 27, 2017; Published: June 13, 2017

*Corresponding author: N C Desai, Department of Chemistry, Maharaja Krishnakumarsinhji Bhavnagar University, Bhavnagar-364002, India, Tel: 0278-2439852; Email: dnisheeth@rediffmail.com

\begin{abstract}
In this mini-review, we have compiled our research group's prior efforts aimed at developing potential, novel and safe antimicrobial agents with improved efficiency by using the hybrid molecular approach on quinoline hybrids. Present mini-review article deals with landscaping of quinoline based bioactive analogues with pyrazoles, thiazoles, 4-thiazolidinones, pyrimidines and 2-pyridones heterocycles. Quinoline motifs containing hybrids with two or more fold antimicrobial activity are described hereby. We have reported a mini review of 174 compounds prepared in our laboratory. The SAR of the most promising compounds is also discussed.
\end{abstract}

Keywords: Quinoline; Antimicrobial agents; Pyrazole; 4-Thiazolidinone; 2-Pyridone

Abbrevations: Ac: Aspergillus Clavatus; An: Aspergillus Niger; Ca: Candida Albicans; Ec: Escherichia Coli; Pa: Pseudomonas Aeruginosa; Sa: Staphylococcus Aureus; Sp: Streptococcus Pyogenes

\section{Introduction}

The ever swelling incidences of infectious resistance pose a major threat to the scientific society and thus the basic requirement for discovery and development of newer and safer anti-microbial agents with novel mode of action is becoming acute [1]. One of the best ways to tackle this type of enormous problem is to synthesize hybrid molecules by uniting two or more bioactive heterocyclic moieties in a single molecular framework. Libraries of privileged heterocyclic structures can be used in place of modified drugs. In continuation to this, the design of molecules is made in such a way that may have lower adverse effects with shorter treatment regimens [2].

Quinoline is a heterocyclic aromatic organic compound having molecular formula $\mathrm{C}_{9} \mathrm{H}_{7} \mathrm{~N}$, possessed by a double-ring structure containing a benzene ring fused to pyridine at two adjacent carbon atoms [3]. Quinoline is a core pharmacophore in the recently developed anti tubercular drugs bedaquiline (TMC207). This is the first drug with a novel mechanism of action for TB in more than 40 years. Bedaquiline a diarylquinoline is the sole drug specifically indicated to treat MDR-TB [4]. It works via inhibition of enzyme adenosine triphosphate (ATP) synthase, which is the energy source for the bacterium. Furthermore, quinoline moiety exhibits biological activities like antibacterial
[5], anti-malarial [6], anti-TB [7], anti-proliferative [8] and anticancer [9].

Table 1: Quinoline clubbed thiazole motifs - (Compounds 1-51).

\begin{tabular}{|c|c|c|c|c|}
\hline Entry & $\mathbf{R}$ & $\mathbf{R}_{\mathbf{1}}$ & $\begin{array}{c}\mathbf{M I C}(\boldsymbol{\mu g} / \\
\mathbf{m L})^{*}\end{array}$ & Organisms \\
\hline 4 & $\mathrm{H}$ & $2-\mathrm{Cl}$ & 12.5 & $A c$ \\
\hline 5 & $\mathrm{H}$ & $4-\mathrm{Cl}$ & 12.5 & $E c$ \\
\hline 6 & $\mathrm{H}$ & $4-\mathrm{F}$ & 12.5 & $P a$ \\
\hline 14 & $\mathrm{H}$ & $4-\mathrm{NO}_{2}$ & 12.5 & $S p$ \\
\hline 15 & $\mathrm{H}$ & $2,4-(\mathrm{Cl})_{2}$ & 12.5 & $S a, A n$ \\
\hline 27 & $\mathrm{H}$ & $4-\mathrm{NO}_{2}$ & 12.5 & $P a, A c$ \\
\hline 37 & $6-\mathrm{CH}_{3}$ & $2-\mathrm{NO}_{2}$ & 12.5 & $P a, A c$ \\
\hline 49 & $6-\mathrm{F}$ & $2-\mathrm{NO}_{2}$ & 12.5 & $P a, A c$ \\
\hline
\end{tabular}

${ }^{*} \mathrm{MIC}$ (in $\mu \mathrm{g} / \mathrm{mL}$ ) of standard drug Ampicillin against: EC (MTCC-443): 100; Pa (MTCC-1688): 100; Sa (MTCC-96): 250; Sp (MTCC 442): 100 \& Griseofulvin against: An (MTCC-282): 100; Ac (MTCC-1323): 100.

According to literature survey, more potent novel chemical entities can be envisaged by uniting two or more heterocyclic systems into a single molecule [10]. With the aim of developing new affordable antimicrobials having new mode of action, our research group is actively involved in developing novel hybrid heterocycles and screen them for antimicrobial activity with 
some more promising results. We have further modified active molecules to develop compounds with more potency and less toxicity. In this article we report here published results of our effort towards development of more potential antimicrobial agents. Since a couple of years our research group has published several important findings for the benefit of scientific community on quinoline based heterocycles. Previously we have published review articles of our own findings which received very well appreciation by scientific community [11,12] (Table 1).

\section{Quinoline clubbed pyrazole motifs - (Compounds 1-51)}

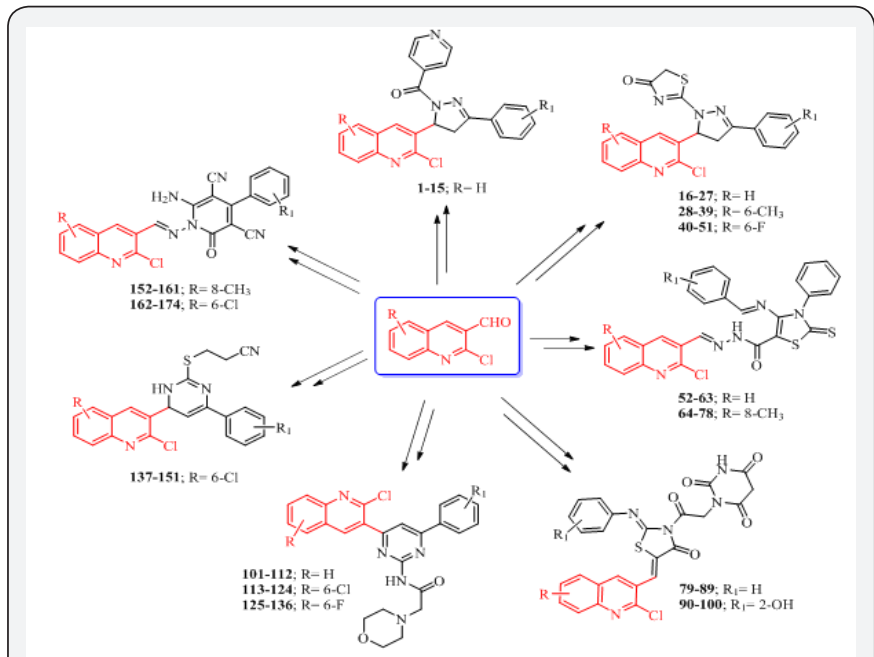

Figure 1: Different molecular diversities based on quinoline hybrid.

Looking at the versatile biological portfolios of quinoline; pyrazole with 4-thiazolidinones and pyridine heterocyclic ring systems, new structural hybrids of three moieties were prepared and subjected to antimicrobial activity [13-15]. Quinoline-pyrazole hybrids 1-15 and 16-51 are shown in Figure 1. Compounds 1-15 substituted with $\mathrm{H}$ at $\mathrm{R}$ and 2-Cl, 4- $\mathrm{Cl}$, $4-\mathrm{F}$ and $4-\mathrm{NO}_{2}$ at $\mathrm{R}_{1}$ position, compounds 4, 5, 6 and 14 came out as most potent antimicrobial agents with MIC of $12.5 \mu \mathrm{g} /$ $\mathrm{mL}$ against various bacterial and fungal strains. Compound 15 displayed excellent antibacterial and antifungal activities against Staphylococcus aureus and Aspergillus niger with MIC of $12.5 \mu \mathrm{g} / \mathrm{mL}$. From the series of compounds 16-51, compound 27 $\left(\mathrm{R}=\mathrm{H}\right.$ and $\mathrm{R}_{1}=4-\mathrm{NO}_{2}$ ) stood out as most promising antibacterial as well as antifungal potency with MIC of $12.5 \mu \mathrm{g} / \mathrm{mL}$ against P. aeruginosa and A. clavatus respectively. Nitro group at ortho position in compounds $37\left(\mathrm{R}=6-\mathrm{CH}_{3}\right)$ and $49(\mathrm{R}=6-\mathrm{F})$ were identified as a most active antimicrobial agents with MIC of $12.5 \mu \mathrm{g} / \mathrm{mL}$ against $P$. aeruginosa and $A$. clavatus strains taking Ampicillin and Griseofulvin as standard drugs.

\section{Quinoline clubbed thiazole motifs - (Compounds 52- 78)}

A series of quinoline clubbed thiazole motifs were synthesized and subjected to antimicrobial evaluation $[16,17]$. Hybrid structure is depicted in Figure 1. Compound $59(\mathrm{R}=\mathrm{H})$ containing 3,4,5-( $\left(\mathrm{OCH}_{3}\right)_{3}$ group showed excellent inhibition $(25 \mu \mathrm{g} / \mathrm{mL})$ against $P$. aeruginosa bacterial strain as compared to the standard drug Gentamycin. Compounds 74 and $78\left(\mathrm{R}=8-\mathrm{CH}_{3}\right)$ containing electron withdrawing substituents such as $-\mathrm{Cl}$ and -F exhibited good antimicrobial activity. It is a well-known fact that electron withdrawing substituents increase the lipophilicity of molecules. This property is directly related to antimicrobial activity as it helps the compound to diffuse through biological membranes and reach the site of action (Table 2).

Table 2: Quinoline clubbed thiazole motifs - (Compounds 52-78).

\begin{tabular}{|c|c|c|c|c|}
\hline Entry & $\mathbf{R}$ & $\mathbf{R}_{\mathbf{1}}$ & $\begin{array}{c}\mathbf{M I C}(\boldsymbol{\mu g} / \\
\mathbf{m L})^{*}\end{array}$ & Organisms \\
\hline 59 & $\mathrm{H}$ & $\begin{array}{c}3,4,5- \\
\left(\mathrm{OCH}_{3}\right)_{3}\end{array}$ & $25^{\mathrm{a}}$ & $P a$ \\
\hline 74 & $8-\mathrm{CH}_{3}$ & $2-\mathrm{Cl}$ & $12.5^{\mathrm{b}}$ & $A c$ \\
\hline 78 & $8-\mathrm{CH}_{3}$ & $4-\mathrm{F}$ & 12.5 & $P a$ \\
\hline
\end{tabular}

${ }^{*} \mathrm{MIC}$ (in $\mu \mathrm{g} / \mathrm{mL}$ ) of standard drug Gentamycin against: $P a$ (MTCC1688): 0.5

${ }^{* b}$ MIC (in $\mu \mathrm{g} / \mathrm{mL}$ ) of standard drug Ampicillin against: $\mathrm{Pa}$ (MTCC1688): 100 \& Griseofulvin against: Ac (MTCC-1323): 100.

\section{Quinoline clubbed 4-thiazolidinone motifs - (Compounds 79-100)}

Table 3: Quinoline clubbed 4-thiazolidinone motifs - (Compounds 79100).

\begin{tabular}{|c|c|c|c|c|}
\hline Entry & $\mathbf{R}$ & $\mathbf{R}_{\mathbf{1}}$ & $\begin{array}{c}\mathbf{M I C}(\boldsymbol{\mu g} / \\
\mathbf{m L})^{*}\end{array}$ & Organisms \\
\hline 86 & $8-\mathrm{OCH}_{3}$ & $\mathrm{H}$ & 12.5 & $S p$ \\
\hline & & & 25 & $A n$ \\
\hline 97 & $8-\mathrm{OCH}_{3}$ & $2-\mathrm{OH}$ & 12.5 & $S p$ \\
\hline
\end{tabular}

*MIC (in $\mu \mathrm{g} / \mathrm{mL}$ ) of standard drug Ampicillin against: Sp (MTCC 442): 100 \& Griseofulvin against: An (MTCC-282): 100.

Owing to the pharmacological importance of 4-thiazolidinones and quinoline, we synthesized new quinoline derivatives containing 4-thiazolidinone moiety and screened them for antimicrobial activity [18-19]. Quinoline containing 4-thiazolidinone structural hybrids were shown in Figure 1 (Compounds 79-100). Compound 86 substituted with $8-\mathrm{OCH}_{3}$ at $\mathrm{R}$ and $\mathrm{H}$ at $\mathrm{R}_{1}$ position displayed MIC of 12.5 and $25 \mu \mathrm{g} /$ $\mathrm{mL}$ against $S$. pyogenes and $A$. niger respectively. Compound 97 exhibited maximum antibacterial inhibition $(12.5 \mu \mathrm{g} / \mathrm{mL})$ against $S$. pyogenes using Ampicillin as standard drug. SAR studies revealed that substitution on quinoline ring at $8^{\text {th }}$ position by an electron releasing groups seems to be better than that of electron withdrawing substitutions (Table 3).

\section{Quinoline clubbed pyrimidine motifs - (Compounds 101-151)}

Pyrimidine analogues play a vital role in drug discovery and its development process, and have significant pharmacological reputation. In view of broad spectrum biological activities of quinolines and pyrimidines, we designed and synthesized new prototypes of quinoline and pyrimidine nucleus in a 


\section{Novel Approaches in Drug Designing \& Development}

single molecular framework and successively evaluated them for antimicrobial activity [20-22]. Structures of quinoline pyrimidine hybrid are represented in Figure 1 (Compounds 101-136 and 137-151). Compound $112\left(\mathrm{R}=\mathrm{H}\right.$ and $\left.\mathrm{R}_{1}=4-\mathrm{NO}_{2}\right)$ demonstrated the most potent antibacterial activity with MIC of $12.5 \mu \mathrm{g} / \mathrm{mL}$ against E. coli and S. pyogenes. Compounds 121 $\left(\mathrm{R}=6-\mathrm{Cl}\right.$ and $\left.\mathrm{R}_{1}=4-\mathrm{F}\right)$ and $122\left(\mathrm{R}=6-\mathrm{Cl}\right.$ and $\left.\mathrm{R}_{1}=2-\mathrm{NO}_{2}\right)$ were identified as the most potent antifungal as well as antibacterial agents with MIC of $12.5 \mu \mathrm{g} / \mathrm{mL}$, respectively. Compound $131(\mathrm{R}=$ $6-\mathrm{F}$ and $\mathrm{R}_{1}=2-\mathrm{F}$ ) exhibited maximum inhibition against $E$. coli. It was observed on the basis of SAR studies that high antimicrobial properties of these compounds may be attributed to the presence of electron withdrawing substituents such as nitro and fluoro at phenyl ring of pyrimidine nucleus. On the other hand, compounds 147 and 149 contain electron donating substituents at para position showed $12.5 \mu \mathrm{g} / \mathrm{mL}$ MIC against Staphylococcus pyogenes and Staphylococcus aureus. In-vitro cytotoxicity of most active antimicrobial compounds $147\left(\mathrm{R}=6-\mathrm{Cl}\right.$ and $\left.\mathrm{R}_{1}=4-\mathrm{OH}\right)$ and $149\left(\mathrm{R}=6-\mathrm{Cl}\right.$ and $\left.\mathrm{R}_{1}=4-\mathrm{OCH}_{3}\right)$ were evaluated against human cervical cancer cell line (HeLa) by MTT colorimetric assay and the tested compounds exhibited any significant cytotoxic effect on HeLa cells, suggesting a great potential for their in-vivo use as antimicrobial agents (Table 4).

Table 4: Quinoline clubbed pyrimidine motifs - (Compounds 101-151).

\begin{tabular}{|c|c|c|c|c|}
\hline Entry & $\mathbf{R}$ & $\mathbf{R} 1$ & $\begin{array}{c}\mathbf{M I C}(\mathbf{\mu g} / \\
\mathbf{m L})^{*}\end{array}$ & Organisms \\
\hline 112 & $\mathrm{H}$ & $4-\mathrm{NO}_{2}$ & $12.5^{\mathrm{a}}$ & $E c, S p$ \\
\hline 121 & $6-\mathrm{Cl}$ & $4-\mathrm{F}$ & 12.5 & $A c$ \\
\hline 122 & $6-\mathrm{Cl}$ & $2-\mathrm{NO}_{2}$ & $12.5^{\mathrm{a}}$ & $E c, S p$ \\
\hline 131 & $6-\mathrm{F}$ & $2-\mathrm{F}$ & $12.5^{\mathrm{b}}$ & $E c$ \\
\hline 147 & $6-\mathrm{Cl}$ & $4-\mathrm{OH}$ & $12.5^{\mathrm{b}}$ & $S p$ \\
\hline 149 & $6-\mathrm{Cl}$ & $4-\mathrm{OCH}_{3}$ & 12.5 & $S a$ \\
\hline
\end{tabular}

${ }^{*} \mathrm{MIC}$ (in $\mu \mathrm{g} / \mathrm{mL}$ ) of standard drug Ampicillin against: Ec (MTCC-443): 100; Sp (MTCC 442): 100

${ }^{*} \mathrm{MIC}$ (in $\mu \mathrm{g} / \mathrm{mL}$ ) of standard drug Ciprofloxacin against: $E C$ (MTCC443): 25; Sp (MTCC 442): 50; Sa (MTCC-96): 50 \& Griseofulvin against: Ac (MTCC-1323): 100.

\section{Quinoline clubbed 2-pyridone motifs - (Compounds 152-174)}

Rich biological silhouette of quinoline and 2-pyridone analogues gave us an impetus to design, synthesis and evaluate new structural hybrids of both these nucleus in single platform $[23,24]$. Quinoline-2-pyridone hybrid is displayed in Figure 1 with compound 152-174. Compound 153 endowed with 4- $\mathrm{CH}_{3}$ substituent revealed remarkable MIC of $62.5 \mu \mathrm{g} / \mathrm{mL}$ against bacterial strain of $E$. coli as compared to the standard drug Gentamycin in. From antibacterial activity data, it was observed that compounds $163\left(\mathrm{R}=6-\mathrm{Cl}\right.$ and $\left.\mathrm{R}_{1}=4-\mathrm{CH}_{3}\right)$ and $164(\mathrm{R}=6$ $\mathrm{Cl}$ and $\mathrm{R}_{1}=4-\mathrm{OCH}_{3}$ ) were identified as most active compounds (MIC $=12.5 \mu \mathrm{g} / \mathrm{mL}$ ) against various Gram-negative as well as Gram-positive bacterial strains. 3-OH analogue possessed maximum inhibition at $12.5 \mu \mathrm{g} / \mathrm{mL}$ against Candida albicans fungal strain (Table 5).

Table 5: Quinoline clubbed 2-pyridone motifs - (Compounds 152-174).

\begin{tabular}{|c|c|c|c|c|}
\hline Entry & $\mathbf{R}$ & $\mathbf{R 1}$ & $\begin{array}{c}\mathbf{M I C}(\boldsymbol{\mu g} / \\
\mathbf{m L})^{*}\end{array}$ & Organisms \\
\hline 153 & $8-\mathrm{CH}_{3}$ & $4-\mathrm{CH}_{3}$ & $62.5^{\mathrm{a}}$ & $E c$ \\
\hline 163 & $6-\mathrm{Cl}$ & $4-\mathrm{CH}_{3}$ & $12.5^{\mathrm{b}}$ & $E c, P a, S a$ \\
\hline 164 & $6-\mathrm{Cl}$ & $4-\mathrm{OCH}_{3}$ & $12.5^{\mathrm{b}}$ & $E c, P a$ \\
\hline 167 & $6-\mathrm{Cl}$ & $3-\mathrm{OH}$ & 12.5 & $C a$ \\
\hline
\end{tabular}

*aMIC (in $\mu \mathrm{g} / \mathrm{mL}$ ) of standard drug Gentamycin against: EC (MTCC-443): 0.25

*bMIC (in $\mu \mathrm{g} / \mathrm{mL}$ ) of standard drug Ciprofloxacin against: $E C$ (MTCC-443): 25; Pa (MTCC 1688): 25; Sa (MTCC-96): 50 \& Griseofulvin against: $\mathrm{Ca}$ (MTCC-227): 500.

\section{Conclusion}

Current article discusses the principle idea for co-relating the structures of potent heterocyclic molecules and antimicrobial activity. The quinoline based molecule classes reported here are pyrazoles, thiazoles, 4-thiazolidinones, pyrimidines and 2-pyridones. Our endeavours to design, synthesis and examine novel quinoline based structural hybrids of various bioactive heterocycles as potential antimicrobial agents have yielded promising results in primary biological evaluation. In our forthcoming efforts, we will assess these structural hybrids and their modified derivatives for further in-vivo studies. The most potent compounds will be validated against various available molecular targets with the goal to produce novel antimicrobial agents with superior remedial effect, minor toxicity and less side effects.

\section{Acknowledgement}

Authors are gratified to the UGC, New Delhi and Department of Science and Technology, New Delhi (DST-FIST-SR/FST/CSI$212 / 2010$ ) for financial support under the NON-SAP and DSTFIST programs, respectively. Dr. Bonny Y Patel is thankful to CSIR (CSIR EMR-II 02(0188)14/EMR-II), New Delhi for CSIR EMR-II Research Associate-I and Mr. Krunalsinh A Jadeja is thankful to UGC, New Delhi for UGC-MRP Project Fellowship (UGC F. No.-43164/2014(SR)).

\section{References}

1. Lie F, Collins JG, Keene FR (2015) Ruthenium complexes as antimicrobial agents. Chem Soc Rev 44(8): 2529-2542.

2. Marson CM (2017) Saturated Heterocycles with Applications in Medicinal Chemistry. Advances in Heterocyclic Chemistry 121: 13-33.

3. Natarajan R, Unnikrishnan PA, Radhamani S, Rappai JP, Prathapan S (2016) Metal-free synthesis of highly substituted quinolines under mild conditions. Tetrahedron Letters 57(28): 2981-2984.

4. Desai NC, Kotadiya GM, Trivedi AR (2014) Studies on molecular properties prediction, antitubercular and antimicrobial activities of novel quinoline based pyrimidine motifs. Bioorg Med Chem Lett 24(14): 3126-3130. 
5. Guo M, Zheng C, Song M, Wu Y, Sun L, et al. (2013) Synthesis and biological evaluation of rhodanine derivatives bearing a quinoline moiety as potent antimicrobial agents. Bioorg Med Chem Lett 23(15): 4358-4361.

6. Vandekerckhove S, D’hooghe M (2015) Quinoline-based antimalarial hybrid compounds. Bioorg Med Chem 23(16): 5098-5119.

7. Kanani MB, Patel MP (2015) Design and synthesis of new (bis) trifluoromethyl-promoted $\mathrm{N}$-aryl biquinoline derivatives as anti tubercular and antimicrobial agents. Medicinal Chemistry Research 24(2): 563-575

8. Tseng C, Tzeng C, Yang C, Lu P, Chen H, et al. (2010) Synthesis and Antiproliferative Evaluation of Certain Indeno[1,2-c]quinoline Derivatives Part 2. J Med Chem 53(16): 6164-6179.

9. Rogdrigues FA, Bomfim IS, Cavalcanti BC, Pessoa C, Goncalves RS, et al (2014) Mefloquine-Oxazolidine Derivatives: A New Class of Anticancer Agents. Chem Biol Drug Des 83(1): 126-131.

10. Rachakonda V, Alla M, Kotipalli SS, Ummani R (2013) Design, diversityoriented synthesis and structure activity relationship studies of quinolinyl heterocycles as antimycobacterial agents. Eur J Med Chem 70: 536-547.

11. Desai NC, Trivedi AR, Pandit U, Dodiya A, Rao KV, et al. (2016) Hybrid Bioactive Heterocycles as Potential Antimicrobial Agents: A Review. Mini Rev Med Chem 16(18): 1500-1526.

12. Desai NC, Pandit UP, Dodiya A (2015) Thiazolidinedione compounds: a patent review (2010 - present). Expert Opin Ther Pat 25(4): 479-488.

13. Desai NC, Patel BY, Dave BP (2017) Synthesis and antimicrobial activity of novel quinoline derivatives bearing pyrazoline and pyridine analogues. Medicinal Chemistry Research 26(1): 109-119.

14. Desai NC, Joshi VV, Rajpara KM, Vaghani HV, Satodiya HM (2013) Synthesis of quinoline-pyrazoline based thiazole derivatives endowed with antimicrobial activity. Indian Journal of Chemistry 52B: 11911201.

15. Desai NC, Joshi VV, Rajpara KM (2013) Synthesis of new quinoline-2pyrazolinebased thiazolinone derivatives as potential antimicrobial agents. Medicinal Chemistry Research 22(8): 3663-3674.
16. Desai NC, Shihory NR, Kotadiya GM (2013) Synthesis of Some Novel 4-(Arylideneamino)-N'-((2-chloro-8-methylquinolin-3-yl)methylene)3-phenyl-2-thioxo-2,3-dihydrothiazole-5-carbohydrazides as Potential Antimicrobial Agents. Letters in Drug Design \& Discovery 10: 632-639.

17. Desai NC, Shihory N, Rajpara KM, Dodiya A (2012) Synthesis, characterization and antimicrobial screening of novel quinoline-thiazole derivatives. Indian Journal of Chemistry 51B: 508513.

18. Desai NC, Satodiya HM, Rajpara KM, Joshi VV, Vaghani HV (2013) Synthesis and Characterization of Clubbed Thiazolidin-4-one, Quinoline and Barbitone Derivatives as a Potent Antimicrobial Agents. Letters in Drug Design \& Discovery 10: 335-342.

19. Desai NC, Satodiya HM, Rajpara KM, Joshi VV, Vaghani HV (2013) Synthesis of somen novel C-5 and N-3 substituted 2-(2-hydroxyphenylimino)thiazolidin-4-one derivatives with broadspectrum antimicrobial activity. Medicinal Chemistry Research 22(12): 6063-6077.

20. Desai NC, Rajpara KM, Joshi VV, Satodiya HM (2013) Synthesis of promising antimicrobial agents: a novel series of $\mathrm{N}-(4$ ( 2,6-dichloroquinolin-3-yl) - 6-(aryl) pyrimidin-2-yl)-2morpholinoacetamides. Medicinal Chemistry Research 22(3): 1172-1183.

21. Desai NC, Rajpara KM, Joshi VV, Vaghani HV, Satodiya HM (2013) Synthesis, characterization and antimicrobial screening of hybrid molecules containing quinoline, pyrimidine and morpholine analogues. Journal of Chemical Sciences 125: 312-333.

22. Desai NC, Rajpara KM, Joshi VV (2012) Synthesis and characterization of some new quinoline based derivatives endowed with broad spectrum antimicrobial potency. Bioorg Med Chem Lett 22(22): 68716875.

23. Desai NC, Harsora JP, Patel BY, Jadeja KA (2015) Synthesis of a novel series of imines containing nitrogen heterocycles as promising antibacterial and antifungal agents. Indian Journal of Chemistry.

24. Desai NC, Harsora JP (2012) Synthesis, characterization and antimicrobial screening of some quinoline based dihydropyridine and 2-oxo-azetidine derivatives. Indian Journal of Chemistry 51B: 10111019.

\section{Your next submission with Juniper Publishers will reach you the below assets}

- Quality Editorial service

- Swift Peer Review

- Reprints availability

- E-prints Service

- Manuscript Podcast for convenient understanding

- Global attainment for your research

- Manuscript accessibility in different formats

( Pdf, E-pub, Full Text, Audio)

- Unceasing customer service

Track the below URL for one-step submission

https://juniperpublishers.com/online-submission.php 